\title{
Biyoloji Öğretmenlerinin Sosyo-Bilimsel Konuların Öğretimine Yönelik Görüşlerinin İncelenmesi*
}

\section{Exploring Biology Teachers' Views on Teaching Socio- Scientific Issues}

\author{
Ganime AYDIN**, Deniz SARIBAŞ***, Dilek ÖZALP****, Şirin YILMAZ *****
}

\begin{abstract}
Öz: Sosyo-bilimsel konular (SBK), temeli bilimsel araştırma sonuçlarına, uygulamalarına veya uygulama sonuçlarında ortaya çıkan problemlere dayalı olan ve çoğunlukla sonuçları canlı yaşamı, doğa üzerinde etkili, toplumsal, ekonomik, politik ve ahlaki olarak tartışmalı konulardır. Bu anlamda, öğrencilerin bilimsel okuryazar olarak eleştirel düşünme becerilerini kullanarak gelecekle ilgili karar verme sürecinde aktif rol alıcılar olarak SBK konularındaki eğitimleri toplumsal boyutta son derece önemlidir. SBK öğretiminde ise fen bilimleri ve biyoloji öğretmenlerinin diğer alanlara göre öğrenciler üzerindeki etkisi ve öğretim programları içeriği açısından daha fazla öne çıkmaktadır. Dolayısıyla bu araştırmada, Biyoloji öğretmenlerinin SBK konularının öğretimini öğrencilerle nasıl gerçekleştirdikleri ve nelere ihtiyaçları olduğunu tespit etmek amaçlanmıştır. Çalışmada nitel araştırma desenlerinden biri olan olgu bilim (phenomenology) kullanılmıştır. Çalışma grubu, 2017-2018 akademik yılı güz yarıyılında Türkiye'nin farklı şehirlerinde görev yapmakta olan on dört Biyoloji öğretmeninden ( 9 kadın, 5 erkek) oluşmuştur. Araştırmacılar tarafindan hazırlanan görüşme formu kullanılarak veriler elde edilmiştir. Öğretmenlerle yüz yüze, telefonla ve yarı-yapılandırılmış görüşmeler yapılmıştır. Verilerin çözümlenmesinde ise araştırma problemlerine göre oluşturulan kategoriler için içerik analiz yöntemiyle kodlar oluşturulmuştur. Görüşmelerin transkripsiyonu, kodlanması ve analizi bu çalışmanın araştırmacılarından ikisi tarafından bağımsız olarak yapılmıştır. Elde edilen sonuçlara göre, öğretmenlerin SBK'nın tanımı, öğretim yöntem ve teknikleri, konu içerik bilgisi ve öğretim materyalleri boyutunda desteğe gereksinimlerinin olduğu tespit edilmiştir.
\end{abstract}

Anahtar Kelimeler: Biyoloji öğretmenleri, biyoloji öğretimi, sosyo-bilimsel konular.

\begin{abstract}
Socio-scientific issues (SSI) are socially, economically, politically and morally controversial issues based on the results of scientific researches, applications or the results of these applications and whose consequences often have an impact on living things and environment. From this perspective, it is significant to integrate SSI in educational programs to educate scientific literate citizens who have critical thinking skills and make informed decisions. Teaching SSI to science teachers and biology teachers come into prominence more than other majors regarding their impact on students and the content of the curriculum. The purpose of this research, thus, was to identify how biology teachers performed SSI education with students and what they needed in this regard. In this study, a phenomenology study, one of the qualitative research designs was used. The study group consisted of fourteen biology teachers $(9$ females and 5 males) working in different cities in Turkey in the fall semester of the 2017-2018 academic year. The data were obtained through face-to-face semi-structured interviews, telephone and internet calls (facetime and skype) using a data collection tool comprising six open-ended questions which were prepared by the researchers. To analyze the data, codes and themes were developed through content analysis method. The transcription, coding, and analysis of the interviews were conducted independently by two of the researchers in this study. According to the obtained results, it was identified that teachers are in need of support in terms of the definition of SSI, teaching method and technique, subject content details, and teaching materials.
\end{abstract}

Keywords: Biology teachers, biology education, socio-scientific issues.

\footnotetext{
*Bu çalışma, 3-5 Temmuz 2018 tarihlerinde II. Ulusal Biyoloji Eğitimi Kongresinde (Aksaray-Türkiye) sunulmuştur. **Doç. Dr., Çanakkale Onsekiz Mart Üniversitesi, Lapseki Meslek Yüksekokulu, Çanakkale/ Türkiye, ORCID: 00000001-6112-5243, e-posta: ganimeaydin@comu.edu.tr

***Doç. Dr., İstanbul Aydın Üniversitesi, Eğitim Fakültesi, İstanbul/Türkiye, ORCID: 0000-0002-4839-7858, e-posta: denizsaribas@gmail.com

****Dr. Öğr. Üyesi, İstanbul Aydın Üniversitesi Eğitim Fakültesi, İstanbul/Türkiye, ORCID: 0000-0002-7817-4866, e-posta: dilekozalp@aydin.edu.tr

******Dr. Öğr. Üyesi, İstanbul Aydın Üniversitesi, Eğitim Fakültesi ABD, İstanbul/Türkiye, ORCID: 0000-0002-02388550, e-posta: sirinyilmaz@aydin.edu.tr
} 


\section{Giriş}

Fen eğitiminin en önemli amaçlarından biri öğrencilerin karar verme becerilerini, verilen kararları uygulamak için gerekli olan bilgi, akıl yürütme, eleştirel düşünme becerilerini içeren bilimsel okuryazarlık gelişimini desteklemektir. Günümüzde, bilimsel okuryazarlık sadece bilimsel bilgiyi içermemekte aynı zamanda, bilimsel bilginin üretilmesini, yorumlanmasını, iletilmesini, müzakere edilmesini ve bilimin topluma ve çevreye olan etkisinin incelenmesini de gerektirmektedir (Organisation for Economic Co-operation and Development [OECD], 2006). Sosyo-bilimsel konular (SBK) "bilimsel kavramlara veya problemlerine dayanan, doğada tartışmalı, toplumsal boyutta tartışılan ve çoğunlukla politik ve etik etkilere tabi olan" konular olarak tanımlanmıştır (Sadler ve Zeidler, 2005). SBK, bilimde önemli olduğu kadar, politik, ekonomik ve ahlaki konuları içerdiği ve tartıştırdığı için toplumsal önem de taşımaktadır (Zeidler, Sadler, Simmons, ve Howes, 2005). SBK, fen konularının uygulanması ve anlaşılması, ahlaki akı1 yürütme, kanıta dayalı tartışmalar yürütme, bilginin gelişimini sağlamasıyla bilimsel okuryazarlık süreçlerini etkili bir şekilde bağlamsallaştıran bir yapıya sahiptir (Sadler, 2009; Zeidler ve Sadler, 2011). Dolayısıyla gelecekte toplumu temsil edecek olan öğrencilerin bilimsel okuryazarlık gelişiminin desteklenmesi için SBK'nın eğitimde yer alması ve fen eğitimiyle bütünleştirilmesi önerilmektedir. Yapılan birçok çalışma ve öneriler SBK öğretiminin, öğrenciler üzerindeki olumlu etkilerini destekler niteliktedir. Örneğin, SBK'nın sınıflarda uygulanmasının; öğrencilerin fen konularını öğrenmelerini sağladığı (Dori, Tal, ve Tsaushu, 2003; Klosterman ve Sadler, 2010; Sadler, Barab ve Scott, 2007), öğrencilerin karar verme süreçlerini etkilediği (Sadler ve Zeidler, 2005; Topçu, 2010), farklı bakış açıları, kanıta dayalı düşünme ve karar verme becerilerini geliştirdiği (Wu ve Tsai, 2007), eleştirel düşünme düzeylerini geliştirdiği (Altuntaş, Yılmaz ve Turan, 2017), öğrencilerin öğrenme motivasyonunu arttırdığı (Dori, Tal, ve Tsaushu, 2003; Parchmann, Gräsel, Baer, Nentwig, Demuth ve Ralle, 2006), öğrencilerin fen alanına olan tutumlarını olumlu yönde geliştirdiği (Lee ve Erdogan, 2007) ve gelecek kariyerlerinde fen alanında eğilimlerini artırdığı (Barber, 2001) belirtilmiştir. Eğitim programlarında SBK öğretiminin yer alması, öğrencilerin bilimi öğrenmelerini, bilim konusundaki anlayışlarını toplumsal tartışmalarda kullanabilmelerini ve hayatlarını etkileyen SBK hakkında bilinçli kararlar alabilmelerini sağlamaktadır (Sadler, Barab ve Scott, 2007). SBK'nin günlük hayatla ilişkili olması ve bilimsel okuryazarlığı geliştirme potansiyeli olması nedeniyle (Reis ve Galvao, 2009) fen derslerinde olması gerektiği önerilmiş (Driver, Newton ve Osborne, 2000) ve birçok fen müfredatında yer verilmiştir (Levinson, 2007).

Türkiye'de de ilk olarak SBK'yi, 2013 yılında Milli Eğitim Bakanlığı (MEB) tarafından fen bilimleri dersi öğretim programında Fen-Teknoloji-Toplum-Çevre (FTTÇ) öğrenme alanı altında yer verilmiştir (MEB, 2013). SBK, yenilenen fen bilimleri öğretim programının özel amaçlarında yer almaktadır. Özellikle çevre sorunları, sağlık ve beslenme konuları vurgulanarak sosyobilimsel konularda muhakeme ve bilinçli değerlendirmeler yapma becerilerinin geliştirilmesi bağlamında yer almaktadır (MEB, 2018). Ancak, SBK'lerle ilgili alanyazında çalışılan genetiği değiştirilmiş organizmalar (GDO), kürtaj, organ nakli gibi programdaki konularla ilişkilendirilebilecek birçok kavramın yeni öğretim programda yer almadığ1 görülmektedir. Dolayısıyla öğretim programlarının uygulayıcısı olan öğretmenlerin, SBK'larla ilgili derslerinde kullanabileceği örnek uygulamaların yer aldığ 1 öğretmen rehber kitabı, web sayfası veya öğretim programında yararlanabilecekleri kaynaklar gösterilmediği sürece SBK'ların etkin bir şekilde ögretilmesi tartışmalı bir konudur. SBK'ların etkin bir şekilde öğretilmesi için Biyoloji öğretmeni yetiştirme programlarının öğretmenlere bu konularda kazandırdığı altyapının bilinmesi gerekmektedir. Bu nedenle, öğretmenlerin SBK' lerdeki bilgi ve algıları ile bunları derslerine nasıl yansıttıklarının araştırılması önemlidir. $\mathrm{Bu}$ bilgiler 1şığında bu çalışmada, Biyoloji öğretmenlerinin SBK'lerin öğretimini öğrencilerle nasıl gerçekleştirdikleri ve nelere ihtiyaçları olduğunu tespit etmek amaçlanmıştır. 


\section{SBK'larda öğretmenlerin bilgi düzeyleri}

Alan yazın incelendiğinde hem Türkiye'de hem de yurt dışında, öğretmenlere ve SBK'ye odaklanan özellikle Biyoloji alanı ile ilgili birçok araştırma gerçekleştirilmiştir. Bu araştırmalarda, öğretmenlerin SBK hakkında bilgileri, SBK'yi sınıflarında uygulamalarıyla ilgili sınırlılıkları ve uygulamalardaki ihtiyaç duydukları yeterlilikleri ortaya çıkaran sonuçlar elde edilmiştir. Örneğin Ekborg, Ottander, Silfver ve Simon (2013) tarafından yapılan bir araştırmada, 55 öğretmenin SBK özelliklerine sahip altı vaka arasından birini seçmeleri istenmiş, uygun buldukları şekilde organize etmeleri sağlanmış böylece öğrencilerin ilgisini ve öğrenmesini nasıl deneyimledikleri açığa çıkarılmaya çalışılmıştır. Araştırma sonunda öğretmenler, SBK'ların ilgi çekici ve güncel konular olduğunu belirtmişler ve öğrencilerin soruları formüle edemediklerini ve tartışmaları verimli gerçekleştiremediklerini tespit etmişlerdir. Araştırmada, öğretmenlerin müfredatta daha fazla hedefi kapsayacak şekilde SBK'yi kullanmaları gerektiği üzerine düşünmeye başladıkları, ancak sadece birkaçının SBK'yi öğretmek için açık stratejiler geliştirebildiği ve çoğunun SBK'yi sadece fen konu içeriğini tanıtırken kullandıkları tespit edilmiştir.

Lee, Abd-El-Khalick ve Choi (2006) yaptığ çalışmada öğretmenlerin, fen derslerinde SBK'ye değinilmesinin bir ihtiyaç olduğunu belirtmelerine rağmen, az sayıda öğretmenin bu tür tartışmalı konuları sınıflarında yer verdikleri görülmüştür. Klonlama konusuna odaklanan bir diğer çalışmada ise 112 fen bilgisi öğretmen adayının ikilemler ve sorular kullanılarak klonlama hakkındaki algıları ve bilgi düzeyleri değerlendirildiğinde, öğretmen adaylarının bilgilerinin çok sınırlı olduğu, çoğunun konu hakkındaki bilgilerini resmi olmayan kaynaklardan edindikleri ve klonlamanın riskli olduğunu düşündükleri belirlenmiştir (Sürmeli ve Sahin, 2012).

SBK öğretiminde Fen bilimleri ve Biyoloji öğretmenlerinin diğer alanlara göre öğrenciler üzerindeki etkisi, öğretim programları içeriği açısından daha fazla öne çıkmaktadır. Bu alandaki öğretmenlerin yeterliliklerinin tespit edilip gerekli olan desteğin verilmesi bilimsel okuryazar bir toplum için bir gereksinimdir. Ülkemizde Biyoloji öğretmenlerinin SBK'yi nasıl algıladıklarıyla ilgili Han-Tosunoğlu ve İrez (2017) tarafından yapılan çalışmada, öğretmenlerin SBK hakkında anlayışlarının yetersiz olduğu tespit edilmiştir. Örneğin 102 öğretmenden 26'sının SBK'yi tanımlamakta zorlandığı, 27'sinin SBK'nin fen eğitimi açısından neden önemli olduğunu açıklamakta sınırlı farkındalığa sahip olduğu, katılımcıların yaklaşık yarısının SBK'nin sınıf içine nasıl dâhil edileceği konusunda yetersiz açıklamalarda bulunduğu dolayısıyla SBK hakkındaki anlayış düzeylerinin sınıf içi uygulamalara yansıdığ 1 sonucuna varılmıştır. Bu çalışmada ise öğretmenlerin SBK nasıl tanımladıkları ve bu konuları sınıflarında nasıl işledikleri ve SBK etkili ve verimli bir şekilde işlenebilmesi için öğretmenlerin nelere ihtiyaçları olduğu tespit edilmeye çalışılmıştır.

\section{Öğretmenlerin SBK’ların öğretimine yönelik görüssleri}

Levinson (2006) tarafından 14-19 yaş grubu öğrencilerle yapılan çalışmada, seksen üç öğretmenin biyotıp ve biyoteknoloji gibi tartışmalı bir SBK'nin öğretilmesi sırasında tartışmalı konulardaki kanıtları nasıl kullandıkları araştırılmıştır. Yapılan mülakatların analizi sonucunda ortaya çıkan üç temel temanın; gerçeklere duyulan ihtiyaç, kanıt güvenilirliği ve geçerliliği ve gerçeklerdeğerler arasındaki kontrastlar olduğu belirlenmiştir. Aynı zamanda, SBK'de kanıtların ögretilmesinde daha fazla destek, odaklanma ve uygulama olması ve tüm bilgi kaynaklarının eleştirel olarak incelenmesi gerektiği vurgulanmıştır. Benzer olarak, Espeja ve Lagaróna (2015) öğretmenlerin argümantasyon gibi üst düzey düşünme becerilerinin kullanılmasının öğrencilerin SBK'yi öğrenmelerinde etkili olduğunu fark edebildikleri halde, bu faaliyetlerin öğrencilerin fen konularındaki bilgilerini geliştirmesine yardımcı olabileceğini fark edemediklerini ve SBK'yi öğretme amaçlarını anlamanın öğretmen adayları için zor olduğunu belirtilmişlerdir. Gürbüzoğlu-Yalmancı ve Gözüm (2016) tarafindan yapılan araştırmada ise GDO'lara yönelik araştırma yapan Biyoloji öğretmen adaylarının oranının, yapmayanların oranına göre daha düşük olduğu gözlemlenmiştir. Öğretmen adaylarının en fazla GDO'ların canlılar üzerindeki etkilerini 
açığa çıkarmayı amaçlayan araştırmalar yapmak istedikleri belirlenmiştir. Bu bulgu ışığında, bu makalede sunulan çalışmada, öğretmenlerin görüşlerinin araştırılacağı SBK'ler arasına GDO da dahil edilmiştir.

SBK'yi sınıf içerisinde yeterince yer verilememesinin nedenleri olarak, öğretmenlerin SBK öğretimi ile ilgili düşük öz yeterlilik inançlarına sahip olmaları, öğretim süresinin yetersizliği ve ilgili materyallerin bulunamaması gösterilmektedir (Kara, 2012; Lee, Abd. El.Khalick ve Choi, 2006). Yine genetiği değiştirilmiş gıdalarla ile ilgili yapılan bir çalışmada, öğretmen adaylarının bu gıdaları riskli buldukları ve olumsuz tutumlara sahip oldukları belirlenmiş, GDO'lu gıdalarla ilgili öğretim yapabilmeleri için öz yeterlik inançlarının orta derecede olduğu belirlenmiştir (Sönmez ve Kılınç, 2012). Klonlama ve genetik mühendisliği ile ilgili bir vaka çalışmasında ise öğretmenlerin SBK ile ilgili tartışma etkinliklerini uygulayabilmeleri, tasarım, yönetim ve değerlendirme yapabilmeleri için yeterli bilgiye sahip olmaları gerektiği sonucuna varılmıştır. Aynı zamanda, bu yeterliliklerin geliştirilmesi, öğretmenlerin uzman gözetiminde yardım ve destek alarak sınıflarında uygulama yapmaları gerektiği vurgulanmıştır (Reis ve Galvao, 2009). Öğretmenlerin, öğrencilerin katılımının teşvik edilmesinin önemini fark ettikleri ancak SBK'lerin sinıfta uygulanma zorluğunu vurguladıkları tespit edilmiştir (Bossér, Lundin, Lindah ve Linder, 2015). SBK temelli öğretim uygulamaları üzerinde öğretmenlerin kendine güvenlerinin ve öğretme isteklerinin çok önemli rol oynadığı ancak öğretim süresi ve okuldaki SBK tabanlı öğretime ilişkin uzmanlıkla ilgili eksikliklerin olması, SBK temelli öğretimin önündeki engeller olarak belirtilmektedir (Pitiporntapi ve Srisakuna, 2017). SBK'nin sınıf içinde öğretiminde kullanılan tartışma yönteminde öğretmenlerin tartışmaları yönetmekte zorlandıkları ve bu konuda kendilerine güvenmedikleri (Simonneaux, 2014), konu hakkındaki fikirlerini siyasi, ahlaki ve etik olarak açıklamak konusunda problemler yaşadıkları tespit edilmiştir (Oulton, Dillon ve Grace, 2004).

Araştırmalardan yola çıkarak, öğretmenlerin SBK'ler hakkındaki bilgileri ve bunları öğretmeleri konusuna araştırmalar yapılmış olmakla beraber alan yazında Biyoloji Öğretmenlerinin çevre kirliliği, GDO, aşı ve organ nakli konusundaki bilgilerini, bu konuların öğretimi sırasında uyguladıkları yöntem ve teknikleri, yararlandıkları kaynaklar ve bu konuları daha etkin bir şekilde öğretebilmeleri için ihtiyaç duydukları unsurları ayrıntılı bir şekilde ele alan çalışmalara pek rastlanmamaktadır. Bu amaçla bu araştırmada, Biyoloji öğretmenlerinin SBK'lerin neler olduğu, SBK öğretimini öğrencilerle nasıl gerçekleştirdikleri ve nelere ihtiyaçları olduğunu tespit etmek amaçlanmıştır. Araştırmanın problemleri ise aşağıdaki gibidir:

1. Biyoloji öğretmenleri SBK'den ne anlamaktadırlar?

2. Biyoloji öğretmenleri SBK öğretimini sınıflarında nasıl gerçekleştirdiklerini ifade etmektedirler?

3. Biyoloji öğretmenleri SBK öğretimini için ne tür kaynaklardan yararlanmaktadırlar?

4. Biyoloji öğretmenlerinin SBK öğretimi için nelere gereksinimleri vardır?

$\mathrm{Bu}$ araştırma, Biyoloji öğretmenleriyle doğrudan görüşme yapılmasıyla araştırma probleminin dışında problemin nedenleriyle ve çözüm önerileriyle ilgili derinlemesine veri elde edilmesiyle farklılık oluştururken, SBK sinıflarda öğretilmesinde öğretmenlerin nelere ihtiyaç duydukları boyutunda ülkemize özgün verilerin elde edilmesi açısından önemlidir.

\section{Yöntem}

\section{Araştırma deseni}

$\mathrm{Bu}$ çalışma nitel araştırma türlerinden olgu bilim çalışmasıdır. Olgu bilimsel bir çalışma, birkaç bireyin bir kavram ya da olguyla ilişkili deneyimlerini nasıl anlamlandırdıklarını tanımlamayı amaçlamaktadır. Olgu bilimciler, bir olgu hakkında katılımcıların deneyimlerini betimlemeye odaklanmaktadırlar (Creswell, 2007). Olgularla ilgili yaşantıları ve deneyimleri ortaya çıkarmak için görüşmeler yapılmaktadır (Büyüköztürk vd., 2018). Bu araştırmadaki olgu, SBK öğretimi konusunda öğretmenlerin görüşleridir. 


\section{Çalışma grubu}

Bu çalışmada biyoloji öğretmenlerinin SBK'leri anlamaları ve bu konuların öğretimine yönelik görüşlerini derinlemesine incelemek amaciyla örneklem seçiminde amaçlı örnekleme yöntemlerinden maksimum çeşitlilik ve ölçüt örnekleme yöntemleri kullanılmıştır. Amaçlı örnekleme derinlemesine incelenmesi gerektiği düşünülen durumların detaylı çalış1lmasına olanak tanımaktadır. Bu bağlamda amaçlı örnekleme yöntemi pek çok durumun, olgu ve olayın keşfedilmesinde ve açıklanmasında faydalı olmaktadır (Patton, 2002). Çalışmada amaçlı olarak çalışmanın odağı olan Biyoloji öğretmenleri seçilmiştir. Amaçlı örnekleme ilgilendiğimiz evrenin özellikleri göz önünde bulundurarak örnek olay ya da durumumuzu dikkatlice seçmemizi gerektirmektedir (Lincoln ve Denzin, 1994). Belli ölçütleri karşılayan ya da belirli özelliklere sahip olan durumlarda çalışılmak istendiğinde bu örnekleme türü tercih edilmektedir (Büyüköztürk vd., 2018). Öncellikle örneklem grubunun çeşitliliği için öğretmenlerin çalıştığ 1 kurumun, eğitim ortamlarının, öğrenci bilişsel düzeyinin farklı olması için devlet ve özel okulda çalışan Biyoloji öğretmeni arayışına gidilmiştir. Bu çalışmada tercih edilen bu örnekleme yönteminde olduğu gibi, incelenen problemle ilgili olarak farklı durumlar belirlenerek, bu durumlar üzerinde çalışılması, amaçsal örnekleme yöntemlerinden biri olan maksimum çeşitlilik örnekleme yöntemi olarak tanımlanmaktadır (Büyüköztürk ve diğerleri, 2018). Burada araştırmacının daha önce birlikte çalıştığı Biyoloji öğretmenleriyle görüşmeler başlamıştır. Bu örnekleme yöntemi de yine amaçsal örnekleme yöntemlerinden biri olan ölçüt örnekleme yöntemine uygundur. Çünkü katılımcılar, belirli özelliklere sahip kişilerden seçilmiştir (Büyüköztürk vd., 2018). Yine öğretmenlerin yabancı kaynakları kullanmasını karşılaştırmak için İngilizce eğitim veren lisans programlarından mezun öğretmenler örneklem gruba eklenmiştir. İnternet erişimi, laboratuvar imkânları, sınıf mevcudu gibi etkenlerin SBK öğretimine etkisi düşünülerek farklı bölgelerden Aydın, Elazı̆̆ Ankara, Ordu illerinde görev yapan Biyoloji öğretmenleri seçilmiştir. Buradaki amaç öğretmenler arasındaki çeşitliliği arttırmakla birlikte katılımcı grubunun sayısını da arttırmaktır. Çalışma, 2017-2018 akademik yılı bahar yarıyılında 14 (9 kadın, 5 erkek) Biyoloji öğretmenin gönüllü katılımı ile gerçekleştirilmiştir. Öğretmenlere ait demografik bilgiler veri toplama aracının ilk sorusundan elde edilmiştir. Buna göre; çalışmaya katılan öğretmenlerin büyük çoğunluğu (8) İstanbul'da görev yaparken, 7'si devlet okullarında, diğer 7'si ise özel okullarda görev yapmaktadır. Araştırmaya katılan öğretmenlerin sadece iki tanesi lisansüstü eğitim (1 yüksek lisans, 1 doktora) almıştır. Yine araştırmaya katılan öğretmenler 18-31 yıl arasında mesleki deneyime sahiptir. Çalışma grubuyla ilgili demografik veriler Tablo 1 'de verilmiştir.

Tablo 1

Çalışma Grubuna Ait Demografik Veriler

\begin{tabular}{llllll}
\hline Kod & Cinsiyet & $\begin{array}{l}\text { Deneyim } \\
\text { y1lı }\end{array}$ & $\begin{array}{l}\text { Çalış1lan Okul Türü } \\
\text { Kamu/ Özel Okulda }\end{array}$ & Görev Yeri & YL / Doktora \\
\hline K20K & Kadın & 20 & Kamu & Aydın & Yok \\
\hline K24Ö & Kadın & 24 & Özel & İstanbul & Yok \\
\hline K18K & Kadın & 18 & Kamu & Ankara & Yüksek Lisans \\
\hline K23K & Kadın & 23 & Kamu & Ankara & Doktora \\
\hline K31Ö & Kadın & 31 & Özel & İstanbul & Yok \\
\hline K25K & Kadın & 18 & Özel & İstanbul & Yok \\
\hline K21K & Kadın & 25 & Kamu & İstanbul & Yok \\
\hline K17Ö & Kadın & 17 & Kamu & İstanbul & Yok \\
\hline E21Ö & Erkek & 21 & Özel & İstanbul & Yok \\
\hline E19K & Erkek & 19 & Kamu & İstanbul & Yok \\
\hline E20K & Erkek & 20 & 16 y1l özel-4 y1l kamu & Çanakkale & Yok \\
\hline E27Ö & Erkek & 27 & Özel & İstanbul & Yok \\
\hline E27K & Erkek & 27 & Kamu & Ordu & Yok \\
\hline
\end{tabular}


Veri toplama süreci 20 öğretmenin katılımı ile başlamış ve 6 öğretmenin görüşmeden çekilmesi nedeniyle 14 öğretmen ile tamamlanmıştır. Bazı öğretmenlerin görüşme sorularına isteksiz cevap vermeleri, cevapları geçiştirmeleri veya ilgili konuya yönelik yeterli bilgi sahibi olmadıklarını ifade ederek görüşmeden çekilmişlerdir. Dolayısıyla bu araştırma 14 Biyoloji öğretmeni ve yar1yapılandırılmış açık uçlu sorularla sınırlıdır. Görüşmeler 10 öğretmenle yüz yüze ve Ordu, Adıyaman ve Çanakkale'deki öğretmenlerle Skype ve Aydın'daki öğretmenle telefonla (facetime) yaklaşık bir saatlik sürede gerçekleştirilmiş olup görüşmelerin tümünün ses kaydı alınmıştır.

\section{Veri toplama araçları}

Çalışmada araştırmacılar tarafından geliştirilen ve alan eğitiminde uzman iki uzman akademisyene danış1ldıktan sonra düzenlenen 'Öğretmen Görüşme Formu' kullanılmıştır. Görüşme formu, üç öğretmenle pilot görüşmenin ardından tekrar düzenlenmiştir. Görüşme formundaki ilk soru mezun olunan okul ve bölüm, mesleki deneyim, görev yapılan şehir ve okullar, lisansüstü eğitim durumları gibi demografik bilgiler elde edilmek için kullanılmıştır. Diğer sorular ise araştırmanın amacı olan SBK ' yi derslerinde ele alıp almama durumlarını, SBK ile ilgili gelişimleri takip etme durumlarını, kullanılan kaynakların neler olduğunu, öğretim süreçlerinde SBK'yi nasıl ele aldıklarını ve daha etkili bir SBK öğretimi için nelere ihtiyaç duyduklarını açığa çıkarmak amaçlı olarak hazırlanmıştır. Ancak her soruda derinlemesine bilgi alınana dek sondaj sorularına yer verilmiştir. Örneğin "Öğretim sürecinizde SBK'yi nasıl işliyorsunuz?" sorusuna doğrudan derste şunu anlatıyorum şunları soruyorum dendiğinde "Ders planınız var mı?", "Çevre kirliliği, GDO, aşı ve organ nakli konusunda sınıf içinde uyguladığınız etkinlikler nelerdir?" ya da "Öğrencilerin aktif olarak katılımıyla gerçekleştirdiğiniz etkinlikler nelerdir?" şeklinde sorularla derinlemesine bilgi elde edilmeye çalışılmıştır. Bu çalışmada, temel odak noktasının gözden kaçırılmaması için 6 soru hazırlanmış, fakat öğretmenin açıklamasının yeterli olmadığının düşünüldüğü ya da öğretmenin soruyu anlamadığı durumlarda ek sorular sorulmuştur.

\section{Yarı-yapılandırılmış görüşme soruları}

1. Sizce SBK (Sosyo-bilimsel konular) nedir? SBK deyince ne anlıyorsunuz? Birkaç örnek verebilir misiniz?

2. Çevre kirliliği, GDO, Aşı, Organ nakli bu konuları derslerinizde işliyor musunuz? Nas1l? (Hangi yöntem ve teknikleri kullanıyorsunuz? Ders planınız var mı?)

3. SBK ile ilgili güncel gelişmeleri takip ediyor musunuz?

4. Derslerinizde SBK için hangi kaynaklardan yararlanıyorsunuz? Neden?

5. SBK'nin öğretiminde zorlanıyor musunuz? Neden? Örnek verir misiniz?

6. SBK'nın etkili öğretimi için neye/nelere ihtiyaç duyuyorsunuz?

$\mathrm{Bu}$ görüşme sorularından SBK anlamaları, bu konuda takip ettikleri güncel gelişmeler, yararlandıkları kaynaklar ile bu konuların öğretimi ile ilgili sorulara genel cevap vermişlerdir. Fakat bu konuları derslerinde nasıl işledikleri ve hangi yöntem ve teknikleri kullandıkları sorusuna teker teker cevap vermişlerdir. Bu konuda görüşmeciler öğretmenleri yönlendirmemiş, genel ya da özel örnekler üzerinden cevap verme tercihinde onları özgür bırakmıştır. Görüşmeler üç araştırmacı (araştırmacı 1, 2 ve 4) tarafından ortalama 40-60 dakika sürede gerçekleşmiştir. Her bir görüşme katılımcıların izni ile kayıt altına alınmış ve ardından iki araştırmacı (araştırmacı 1 ve 4) tarafından transkript edilmiştir.

\section{Verilerin analizi}

Araştırmanın geçerlik ve güvenirlik süreçlerinde Lincoln ve Guba (1985) tarafından ileri sürülen doğal sorgulama (naturalistic inquiry) kapsamındaki geçerlilik ve güvenilirlik süreçlerinden yararlanılmıştır. Öğretmenlerin SBK'ye yönelik genel öğretim eğilimlerini belirlemek amacıyla geliştirilen görüşme sorularının oluşturulma sürecinde Biyoloji eğitimi alanında uzman iki akademisyenin görüşleri alınmıştır. Verilerin analizinden önce araştırma sorularının odak 
noktalarına göre fen eğitimi alanında uzman iki akademisyen (araştırmacı 2 ve 3) tarafından kategoriler oluşturulmuştur.

\section{Geçerlilik ve güvenilirlik analizleri}

Elde edilen verilerin betimsel analizinde çalışmada yer alan iki araştırmacı (araştırmacı 2 ve 3) birbirinden bağımsız olarak, katılımcıların verdiği cevaplara göre kodlar oluşturarak verileri analiz etmiştir. Bu iki araştırmacı arasındaki başlangıçtaki fikir birliği \%80'dir. Araştırmacılar, bir araya gelerek kodlar arasındaki uyum \%100 (Miles ve Huberman, 1994) olana dek analizleri tekrarlamışlardır. Kategoriler ise araştırma sorularının odak noktalarına göre yapılandırılmıştır. Nitel araştırmalarda geçerliği sağlamak amacıyla araştırmacıların araştırdıkları konuyu olduğu gibi ortaya koymaları ve elde ettikleri verileri olabildiğince yansız sunmaları gerekmektedir. Bu ise araştırmacıların araştırılan durum hakkında bütüncül bir resim oluşturmasında önem arz etmektedir. Yine benzer şekilde elde edilen veriler ile araştırmanın geçerlik ve güvenirliğini güçlendirmek için öğretmenler ile yapılan görüşmeler esnasında katılımcı görüşlerinin daha anlaşılabilir ve ayrıntılı şekilde alınabilmesi için görüşmeye yeni sorular eklenmiş, katılımcıların sunduğu görüşlerin teyit edilmesi sağlanmış (katılımcı teyidi); elde edilen veriler katılımcı teyitleri ile birlikte ayrıntılı betimlenmiş, araştırma konusu günlük yaşamı da ilgilendiren SBK ve ögretimi bağlamında ilgili konuya hem gerçek yaşamla bağdaştırılmış hem de bilimsel çerçevede ele alınmıştır.

Tablo 2

Kategorilerin Odakları

\begin{tabular}{|c|c|}
\hline Kategoriler & Odakları \\
\hline SBK'yi Anlama & $\begin{array}{l}\text { SBK'lerin neler olduğunun belirtilmesi, SBK nedir } \\
\text { tanımlanabilmesi, biyoloji programında hangi ünite } \\
\text { ve konuların içinde yer aldığının belirtilebilmesi, } \\
\text { toplumsal yaşamla ilişkisi, etik ve ahlaki } \\
\text { boyutlarından bahsedilmesi beklenmiştir. }\end{array}$ \\
\hline SBK Örnekleri & $\begin{array}{c}\text { Çevre kirliliği, GDO, aşı ve organ nakli } \\
\text { konularındaki alan bilgileri ve dersin öğretimsel } \\
\text { boyutunun nasıl gerçekleştiği, ders planları ve bu } \\
\text { örnek konuları derslerinde işleyip işlemedikleri } \\
\text { bilgilerine odaklanılmıştır. }\end{array}$ \\
\hline SBK'lerin Genel Öğretim Süreci & $\begin{array}{l}\text { SBK öğretimde kullandıkları yöntem ve teknikleri } \\
\text { içerir. Özellikle öğrencilerin doğrudan aktif } \\
\text { katılımını sağlayan yöntem ve tekniklerin kullanım } \\
\text { durumu dikkate alınmıştır. }\end{array}$ \\
\hline SBK Öğretimi Sırasında Yararlanılan Kaynaklar & $\begin{array}{l}\text { Konu bilgisi ve öğretim yöntem ve teknikler için } \\
\text { yararlanılan kaynak çeşitliliği dikkate alınmıştır. }\end{array}$ \\
\hline SBK'nin Öğretimine Yönelik İhtiyaçlar & $\begin{array}{l}\text { Eğitim ortamı, öğretmen yeterlilikleri, pedagojik } \\
\text { yeterlilikler, alan bilgisi, öğretim materyali ve } \\
\text { kaynaklar boyutunda ihtiyaçlar dikkate alınmıştır. }\end{array}$ \\
\hline
\end{tabular}

Betimsel analizde, görüşülen bireylerin görüşlerini nesnel bir şekilde yansıtmak amacıyla doğrudan alıntılara sık sık yer verilir. Bu tür analizde amaç, elde edilen bulguları belirlenen tematik çerçeveye göre verileri işleyip bulguları tanımlayarak ve yorumlayarak okuyucuya sunmaktır. $\mathrm{Bu}$ amaçla elde edilen veriler, önce sistematik ve açık bir biçimde betimlenir. Daha sonra yapılan bu betimlemeler açıklanır ve yorumlanır, neden sonuç ilişkileri irdelenir ve ilişkilere yönelik sonuçlara araştırma sorularının kategorileri (temaları) kapsamında ulaşılarak cevap verilir. Ortaya çıkan kategorilerin ilişkilendirilmesi, anlamlandırılması ve ileriye yönelik tahminlerde bulunulması da araştırmacının yapacağı yorumların boyutları arasında yer alabilir. $\mathrm{Bu}$ sayede katılımcılardan elde edilen veriler ilgili kategoriler altında düzenlenerek sunulur. (Yıldırım ve Șimşek, 2016). Verilerin analizinde öğretmenlere cinsiyet, deneyim yılı ve çalıştığ kurumun özel veya kamu olması durumuna göre (Örneğin, kadın, 20 y1llık özel okulda 
öğretmen=K20Ö, erkek 27 y1ldır kamuda öğretmen=E27K gibi) kodlama verilerek analizler yapılmıştır. Kategorilerin tanımı Tablo 2'de verilmiştir.

\section{Bulgular}

Biyoloji öğretmenlerinin verdikleri cevapları araştırmam problemlerinin temel alındığı kategoriler çerçevesinde 5 farklı kategoride toplanmıştır. Bu kategoriler sırasıyla; SBK'lerin tanımı, SBK örnekleri (çevre kirliliği, GDO, aş1 ve organ nakli), SBK'lerin öğretimi, öğretim sırasında yararlanılan kaynaklar ve SBK'lerin öğretimine yönelik öneriler ve beklentilerdir.

\section{SBK'leri anlama}

SBK'ler, hem bilimsel, hem de sosyal konuları içeren, fen ve teknolojiyle de etkileşimi olan, etik, ahlaki ve yasal ikilemleri içinde barındırdığı için bireylerin karar verme süreçleri açısından tartışmalı ve karmaşık konulardır (Topçu, 2015). Bu tanımdan yola çıkarak, SBK'lerin tanımı ile ilgili öğretmenlerin bilimsel; sosyal (toplumsal); birey; fen ve teknoloji; etik, ahlaki ve yasal ikilemler; tartışmalı; karmaşık; karar verme olmak üzere 8 farklı kodla cevaplar vermesi beklenebilir. Ancak bu çalışmada, öğretmenlerin verdiği cevapların bazıları farklı olmak üzere 9 farklı koda ulaş kullanılmıştır. Bu kodlar Tablo 3 'te görülmektedir.

Tablo 3

SBK'lerin Tanımı ile Illgili Kategorinin Kodları, Sıklık ve Yüzde Dağılımları

\begin{tabular}{cccc}
\hline Kodlar & Siklık & Kodlar & Sıklık \\
\hline Toplumsal & 7 & İkilem & 1 \\
\hline Bilimsel & $6)$ & Karar verme / sorun çözme & 1 \\
\hline Birey / insan & 3 & Ekonomi & 1 \\
\hline Çevre ve ekoloji & 3 & Sanat & 1 \\
\hline Teknoloji & 2 & &
\end{tabular}

Tablo 3'te görüldüğü gibi, ögretmenlerin yaklaşık yarısının SBK'lerin bilimsel ve toplumsal konularla ilişkili olduğunu biliyor oldukları görünmektedir. Ancak, bu durumun görüşme sırasında SBK'nin tanımını sorarken kullanılan "sosyal" ve "bilimsel" kelimelerinden kaynaklanıp kaynaklanmadığını anlamak için öğretmenlerin SBK'ler ile ilgili verdikleri örnekler incelenmiştir. Öğretmenlerden birkaçı SBK'lerden birer örnek vermekle birlikte SBK ile ilgili olarak çevre, sağlık, gıda, vb. konuları kapsayacak yeterli çeşitlilikte örnek vermedikleri görünmektedir. Görüşülen öğretmenler çoğunlukla çevre sorunlarını örnek olarak gösterirken, biri GDO ve biyoteknoloji, ise popülasyon genetiği ve evrim örneğini vermiştir. SBK'lerin bireylerde ve toplumda yarattığ ikileme ise sadece bir öğretmen değinmiştir. Görüşme yapılan öğretmenlerden birinin, aklına TÜBİTAK ve şehitlere yardım gibi daha önce yapmış oldukları proje konuları ve projelerde çalıştıkları kuruluşlar gelmiştir. Öğretmenlerin üçünün ise SBK' lerin insan ve çevre ile ilgili olduğunu düşündükleri belirlenmiştir. Bunların yanı sıra, dört öğretmenin SBK terimini hiç duymadığını ifade etmesi, bir öğretmenin ise SBK'lerle ilgisiz olan bir konuya, sanata değinmesi, öğretmenlerin SBK derslerinde işliyor olmasına rağmen terim olarak SBK kelimesine pek aşina olmadıklarını ve tanımını yapamadıklarını göstermektedir. Bu bulgular, öğretmenlerin SBK'ler ile ilgili bilimsel olarak SBK'nin tanımını anlamlandıramadıklarını göstermektedir. Öğretmen cevaplarından örnekler aşağıdaki gibidir:

K23K: "Çevre konularl, Biyoloji konularl, ekoloji konulart. Biyolojinin ekonomiye olan etkisi. Örneğin çevre sorunları, ekonomideki uygulamaları. Mesela yapay deri, yapay kar, insülin üretimi gibi." (Çevre ve ekoloji). 
K18K: "Çevre geliyor. Çevrenin canl organizmalar üzerinde etkileri ve çevre kirliliklerinin ya da doğal ortamda yaşananlar. Onun dışında sanat. Sanatın insan üzerinde duygusal, olumlu etkileri. Şu anda pek örnek gelmiyor." (Çevre ve ekoloji).

E20K: "Popülasyon genetiği, evrim gibi konular geldi hocam doğru mu acaba?" (Bilimsel).

K20K: “Aklıma TÜBITTAK konularl geliyor.” (Bilimsel).

Öğretmenlerin SBK tanımını yapamamış olması onların çeşitli SBK örneklerinde bilgisi olup olmadığı sorusunu da akla getirdiği için ve araştırmanın diğer sorularına verecekleri cevapların geçersiz olacağı için görüşme sırasında öğretmenlere SBK ile ilgili çeşitli örnekler verilip bunları derslerinde nasıl ele aldıkları sorulmuştur. Örnekler verildiğinde ise örneklem grubun tamamının SBK'nin örnekleri hakkında doğal olarak bilgi sahibi oldukları ancak bu konuların SBK olarak tanımlandığını duymadıklarını ifade etmişlerdir.

\section{SBK'lerin öğretiminde izlenen yollar}

Öğretmenlere aşağıdaki SBK konu başlıkları verilip bunları derslerinde nasıl işledikleri sorulmuştur. Her bir konu başlığında öğretmenlerin verdiği cevaplar aşağıda açıklanmaktadır. Çevre Kirliliği: Kendilerine verilen SBK örnekleri içerisinde öğretmenlerin cevap çeşitliliği en çok çevre kirliliği konusunda olmuştur. Bu kategoride öğretmen cevaplarından oluşturulan kodlar, sıklık ve yüzdeleri Tablo 4 de verilmiştir.

Tablo 4

Çevre Kirliliği Konusunun Öğretimi ile Illgili Kategorinin Kodları, Sıkllk ve Yüzde Dă̆llımları

\begin{tabular}{cccc}
\hline Kodlar & Siklık & Kodlar & Siklık \\
\hline Özel örnek & 5 & Uluslararası anlaşmalar & 1 \\
\hline Genel örnek & 4 & Laboratuvar & 1 \\
\hline Soru-cevap & 3 & Gezi & 1 \\
\hline Düz anlatım & 2 & Bireysel çalışmalar & 1 \\
\hline Video ve diğer görseller & 2 ) & Grup çalışmaları & 1 \\
\hline Seminer ve konferanslar & 1 & $\begin{array}{c}\text { Organizasyonlarla etkileşim } \\
\text { (KATEGORİ Vakfı gibi) }\end{array}$ & 1 \\
\hline
\end{tabular}

Öğretmenlerin verdiği genel örnekler karbon ayak izi, atıklar, asit yağmurları, hava, su, toprak, ses, vb. kirlilikleridir. Verdikleri özel örnekler ise, KYOTO Protokolü, 3. Köprünün etkileri, lağım kokulu deniz şeklinde sıralanabilir. Bir öğretmen öğrencilerinde çevre bilinci olduğunu ifade etmiş, bir diğeri ise öğrencilerinin çevre ile ilgili konularda diğer SBK'lere göre daha aktif olduğunu belirtmiştir. Bir başka öğretmen çevre konusuna takıntılı olduğunu, bu konuda projeler yapmak istediğini ama okul yönetiminin buna izin vermediğini vurgulamıştır. Öğretmenlerin verdikleri cevaplardan Örnekler şöyledir:

K23K: "Konferans düzenliyoruz. Her ögrenci arkadaşı ile hazırlanıyor. Seminer gibi işliyoruz. Öğretim programında var, bolca tartışmalı geçiyor. Çevre ile ilgili konularda genelde müfredata bağll gidiyoruz. Çevre konusu son konu oluyor genelde. Ama ögrenciler daha aktif. Öğrenciler seminer düzenliyor ve paslaşıyorlar. Aktif şekilde çevre konuları ortak çalışma konusu olabiliyor. 11. Sinıf coğrafya ile ilişkilendirebiliyoruz." (Seminer ve konferanslar).

K18K: "Deneysel bir ortam, uygun bir ortam yok içeriğinden kaynakll. Okulda kapsaml bir ortam yok. Konu ile ilgili olan kavram, örneklendirmelerden, konu ile ilişkili olan çocuklarda modelleme tarzı etkinlikler kullanıyoruz. Kendi bölgemizde konuyu destekleyen geziler düzenliyoruz." (Video ve diğer görseller, gezi). 
E20K: "Mesela 1993 Ístanbul'daki Hekimpaşa çöp patlamasını açıyorum internete gösteriyorum.” (Video ve diğer görseller).

K18Ö: "Hava, su, toprak, gürültü, ses, vb. kirlilikleri, karbon ayak izi, KYOTO Protokolünden bahsediyorum." (Düz anlatım).

Analiz sonuçları, öğretmenlerin çevre konularıyla ilgili derslerini farklı yöntemler kullanarak anlattıklarını göstermektedir. Bazı öğretmenler soru-cevap (\%21) ve düz anlatım (\%21) yöntemlerini kullanırken bazılarının ise video ve diğer görselleri (\%14) kullandıkları belirlenmiştir. $\mathrm{Bu}$ bulgular, öğretmenlerin çevre konularını daha çok geleneksel öğretim yöntemleriyle islediklerini göstermektedir. Öğrencinin aktif katılımını sağlayan bireysel çalışmalar ve grup çalışmaları ile çeşitli organizasyonlarla etkileşime geçmek gibi uygulamalar öğretmenler tarafından nadiren kullanılıyor gibi görünmekle birlikte araştırma ve argümantasyon gibi yöntemlere ise neredeyse hiç başvurmadıkları ve çöp patlaması gibi öğrencilere sunulan örneklerin güncel olmadığı da dikkat çekmektedir.

\section{GDO}

Öğretmenlerin bu konuyla ilgili verdikleri cevaplar 7 farklı başlıkta kodlanmıştır. Öğretmen cevaplarının sıklık ve yüzde dağılımları Tablo 5 'te görülmektedir.

Tablo 5

GDO Konusunun Öğretimi ile İlgili Kategorinin Kodları, Siklık ve Yüzde Dağılımları

\begin{tabular}{cccc}
\hline Kodlar & Sıklık & Kodlar & Sıklık \\
\hline Özel örnek & 3 & Eleştirel bakış açısı & 2 \\
\hline Düz anlatım & 3 & Araştırma & 1 \\
\hline İkilem & 2 & Uzmanlarla görüşme & 1 \\
\hline Tartışma / münazara & 2 & & \\
\hline
\end{tabular}

$\mathrm{Bu}$ sonuçlar, öğretmenlerin GDO konusunu da farklı yöntemlerle anlattığını göstermektedir. Öğretmenlerden ucunun GDO konusunun öğretiminde düz anlatım yöntemini kullandıkları belirlenmiştir. Üç öğretmenin ise konunun öğretiminde kullandıkları örnekler; mısır, altın pirinç, bakterilerden yün üretilmesi, folik asit eksikliğinin anne ve çocuktaki etkileri, nanoteknoloji ve biyoteknoloji şeklinde sıralanabilir. GDO konusunun öğretiminde soru-cevap yöntemini kullanan bir öğretmen şöyle cevap vermiştir:

E21Ö: “Öncellikle keçi sütü, örümcek a ğg, bakterilerden yün üretilmesi (İTü de ögrencim var ondan alıyorum haberleri). Öğrencilere bunun mümkün olup olmadiğını soruyorum. Misır konusu altın pirinç örneklerini veriyorum. Maalesef sisteme bizde uyup anlatım soru cevap yapıyoruz." (Özel örnek).

Öğretmenlerden beşi bu konuyla ilgili olarak GDO'lu ürünlerin avantaj ve dezavantajlarından bahsettiklerini belirtmişlerdir. İki öğretmen bu konudaki etik ve ahlaki ikilemlerden söz edip bu ürünlerin kullanımının gerekliliği konusunda emin olamadıklarını vurgulamışlardır. Öğretmenlerden birinin yaptığı aşağıdaki açıklama buna örnek olarak gösterilebilir:

K21K: “GDO’larla ilgili muallaktayım. Dünya nüfusu fazla olduğu için gerekli. Ama ögrencilere bunu söylediğim zaman, öğrencilerim o zaman dünyadaki açlı̆̆ın neden bitmediğini, neden GDO'lu ürünlerin zaten alım gücü olan bizim gibi insanlara satıldı̆̆ını soruyorlar. Buna bir cevap veremiyorum. Çocuklar çok sorgulayıcı. Bunun yanı sıra, kısirlı, alerjik etkiler gibi riskler de var. İsrail'den alınan tohumlar konusunda da şüphelerim var. Bize etkileri ne olacak? Bunu bilmiyorum. Öğrencilere olumlu ve olumsuz yönlerini vurguluyorum, eleştirel bir bakış açısıyla. " (İkilem). 
Eleştirel bakış açısına görüşülen öğretmenlerden yalnızca ikisinin değinmiş olması, öğretmenlerin genel olarak bu konuda öğrencilerinin karar verme süreçlerinde eleştirel bir değerlendirme yapmasını sağlayacak durum ve ortamlar hazırlamadığı çıkarımını beraberinde getirmektedir. $\mathrm{Bu}$ bulgudan yola çıkılarak, bu konuda öncelikle öğretmenlerin konu içeriği bilgilendirilmesinin gerektiği sonucuna varılabilir. Aşağıdaki örnek ifadeler Biyoloji öğretmenlerinin konu içeriğine ait bilgilerinin yetersiz olduğunu göstermektedir:

E27Ö: "Doçent bir arkadaşımdan ögreniyorum. Bir öğrencimin sorusu üzerine de biraz araştırma yaptım. Ama fazla bilgim olduğunu söyleyemem." (Uzmanlarla görüşme).

K31Ö: "GDO, biyoteknoloji konusu olarak bir islahlaşma konusu içinde ele altyoruz. Bitki, hayvan ıslahı içinde ele alıyoruz. Güncel tartışarak, teknoloji kullanarak sunu hazırliyoruz. Sunu, konferans. Son çalışmalara bakiyoruz, kim ne demiş inceliyoruz. Deney imkânı da yok bu konuda. Ancak yapılmış deneyler üzerinde (ABD misır bitkisi ile, insanların başına neler gelmiş, zararı var mi yok mu, tartışıyoruz. Misır ile GDO önce yem amaçl mesela, sonra insanlar kullanmaya başlıyor. Alerjik tepkimeler ortaya çıkıyor. Bildiğim bu. Bunun bitkilere zararı yok diye biliyorum.... GDO, gen terapisine geçiş, düz geleneksel yöntem ile ele alıyoruz. Sonra sonucu veriyoruz ve tartışma yapıyoruz." (Düz anlatım, tartışma/münazara).

GDO'nun sınıf içinde öğretimi ile ilgili elde edilen bulgular öğretmenlerin daha çok geleneksel yöntemleri kullandığı ancak SBK'nin öğretiminde etkili olan argümantasyon gibi öğretim yöntemlerini kullanmadıkları görülmektedir. Uygun öğretim yöntemlerinin kullanılmıyor olması öğretmenlerin hem SBK'ler ile ilgili yeterli bilgi ve beceriye sahip olmamalarından hem de SBK'lerin nasıl öğretilmesi gerektiği ile ilgili bilgilerinin yetersiz olmasından kaynaklandığı söylenebilir.

Aşı

Aşı konusunun öğretimi ile ilgili verilen cevaplar Tablo 6'da yer almaktadır.

Tablo 6

Aşı Konusunun Öğretimi ile İlgili Kategorinin Sıklık ve Yüzde Dağılımları

\begin{tabular}{cc}
\hline Kodlar & Siklk \\
\hline İkilem & 1 \\
\hline Özel örnek & 1 \\
\hline Pano hazırlama & 1 \\
\hline Tartışma & 1 \\
\hline Örneklere ulaşma & 1 \\
\hline
\end{tabular}

Aşı konusu, öğretmenlerin en az açıklama yaptığı ve en az uygulama örnekleri sundukları SBK konusudur. Bir öğretmen Türkiye'deki aşı uygulamalarına değindiğini söylemiş, diğerleri derslerde kullandıkları yöntemlerden bahsetmiştir. Bir öğretmen konu ile ilgili pano hazırlama etkinliği yaptırdığından bahsederken yalnızca bir öğretmen toplumdaki aşı karşıtı kampanyalara ve bununla ilgili tartışmalara değinmiştir. Bu öğretmen aşı üretiminin belli firmaların elinde olduğunu, bu yüzden üretilen aşılara güvenmediğini, kendi aşımızı üretmemiz gerektiğini vurgulamıştır. Aşı konusunun öğretiminde uygulama yaptığını belirten bir öğretmenin cevabi şöyledir:

K18K: "Öğrenciler sağlık meslek lisesi olduğu için, aşı konusunu ve ayrıca çocuk genetiğini de biliyorlar. Kendi ulaşabildikleri örneklere ulaşabilmelerini istiyorum. Ben 9, 10. Sinuflara giriyorum. 11 ve 12. Sinfflar staja gidiyor. 9 ve 10. Siniflar ile uygulama yapabiliyoruz. Staja gidenler ise hastane deneyimi kazaniyorlar. Hangi hastalıkta hangi aşı gibi." (Örneklere ulaşma). 
Görüşme yapılan diğer öğretmenler bu konuya hiç değinmemişlerdir. Bu bulgulardan, öğretmenlerin aşılar konusunda bilgilendirilmesi ve bunları öğretime entegre etmelerinin sağlanması gerekliliği ortaya çıkmaktadır.

\section{Organ Nakli}

Öğretmenlerin bu örnekte verdikleri cevaplar Tablo 7’ de verilmiştir.

Tablo 7

Organ Nakli Konusunun Öğretimi ile İlgili Kodların Sıklık ve Yüzde Dağıllmları

\begin{tabular}{cccc}
\hline Kodlar & Siklık & Kodlar & Siklık \\
\hline Önemi & 3 & Uzmanlarla görüşme & 1 \\
\hline Etik kaygı & 2 & Proje & 1 \\
\hline Haber, TV programı & 1 & Sosyal sorumluluk kampanyası & 1 \\
\hline Araştırma & 1 & Bilimsellik & 1 \\
\hline
\end{tabular}

$\mathrm{Bu}$ örnekte de öğretmenlerin üzerinde durduğu noktaların çeşitlilik gösterdiği görülmektedir. Organ naklinin önemi ve bu konudaki etik kaygılar başta olmak üzere, öğretmenlerin önemsediği konular araştırma ve projelerin yanı sıra, sosyal sorumluluk kampanyası ve uzman görüşleri olarak ortaya çıkmıştır. Fakat bunların her biri az sayıda öğretmen tarafından vurgulanmıştır. Öğrencilerin aktif katılımını sağlayan yöntem ve tekniklerin az sayıda öğretmen tarafından uygulanıyor görünmektedir. Bu örnekte dikkat çeken bir nokta, öğretmenlerden birinin bilimsellik konusuna vurgu yapmış olmasıdır. Öğretmenin bu konudaki yorumları aşağıda verilmektedir:

K32Ö: "Organ nakli derken, ders kitaplarında okuma parçası ile ele alınıyor. Taraf değil. Ögrrenciler çok iyi değil. Bilimsellik yok. Eskiden daha ideolojistlerdi. Şimdi daha çok cennete tam gitme taraftarı olduğunu söylüyorlar. Cennet, cehennem kavramları ortaya çıkıyor. 32 yıllık öğretmenim, iyilik yapmak yerine organ vermeme, duyarsızlaşmaların oluştuğunu görüyorum. 12. siniflar sinıfta tartısmaya yöneliyor. Bir an önce ders bitsin istiyorlar." (Etik kayg1, bilimsellik).

$\mathrm{Bu}$ öğretmen, organ nakli konusunun bilimsel bir şekilde ele alınması gerektiğini vurgulamıştır, fakat buna yönelik somut bir öneri sunmamıştır. Aynı öğretmen SBK'lerin genel öğretimine yönelik bir planı olmadığını, ama sınıfta tartışma yaptırdığını söylemiştir. Bir başka öğretmen organ nakliyle ilgili etik kaygılarından söz etmiş, ama bunu öğrencilerine yansıtmadığını, sadece organ naklinin önemine vurgu yaptığını ifade etmiştir. Bu bulgular, yine öğretmenlerin bu konulardaki tartışmaları sınıflarında nasıl yapılandıracakları ve yönetecekleri, kendi fikirleri dışındaki fikirlerde nasıl davranacakları konusunda ikilemde oldukları ve yeterli bilgiye sahip olmadıkları sonucunu ortaya çıkarmaktadır.

\section{SBK'lerin öğretimi}

Öğretmenlerin tek tek SBK örneklerine verdikleri cevabın ardından onlara genel olarak bu konuların öğretimi sırasında hangi uygulamaları gerçekleştirdikleri sorulmuştur. Öğretmenlerin bu soruya verdikleri cevaplar çok çeşitlidir. Bu kategorinin kodları, sıklık ve yüzde dağılımları Tablo 8'de görülmektedir.

Tablo 8

SBK'lerin Genel Öğretim Süreci ile İlgili Kodlar, Sıklık ve Yüzde Dă̆glımları

\begin{tabular}{cccc}
\hline Kodlar & Siklık & Kodlar & S1klık \\
\hline Tartışma & 5 & Okuma ve yazma & 1 \\
\hline Video, film ve görseller & 5 & Gözlem & 1 \\
\hline Araştırma ve proje & 3 & Poster ve sunum & 1 \\
\hline Düz anlatım & 2 & Gerekçelendirme & 1 \\
\hline Soru-cevap & 2 & İnformal değerlendirme & 1 \\
\hline Modelleme & 2 & Uzmanla iletişim & 1 \\
\hline
\end{tabular}


Öğretmenlerin SBK'lerin öğretimi sırasında kullandıkları yöntem ve teknikler çeşitlilik göstermekle birlikte ders planı hazırlamadıkları ancak dersi nasıl işlediklerini özetlediklerinde genel olarak izledikleri yolun aşağıdaki gibi olduğu belirlenmiştir:

- Öncelikle sorular, tanımlar ve görsellerle konuya giriş,

- Daha sonra tartışmalar ve bazen grup çalışmastyla birlikte araştırma,

- Öğrencilerin düşüncelerini ifade etmesinin ardindan ögretmenin konuyu toparlamast ile son bulur.

Bu tür bir planda en dikkat çekici olan unsur, öğretmenlerin grup çalışması, araştırma projeleri ve tartışmaları nasıl organize ettiğini açıklamamış olmalarıdır. Grup çalışmasını nasıl yapıyorsunuz diye detaylı soru yöneltildiğinde genelde poster hazırlama, dönem projesi gibi cevaplar alınmıştır. Bu bulgudan yola çıkarak, öğretmenlerin, grup çalışması, araştırma ve tartışmaları planlamadığ ortaya çıkmaktadır. Bazı öğretmenlerin ise düz anlatım, soru-cevap ve modelleme yöntemlerini kullandıkları; gözlem, poster ve uzmanlarla iletişim gibi yöntemlerin az sayıda öğretmen tarafından kullanıldığı belirlenmiştir.

\section{SBK'lerin araștırılması ve öğretilmesi için yararlanılan kaynaklar}

Öğretmenlere, SBK ile ilgili araştırma yaparken ve SBK'lerin sınıf içerisinde öğretimi sırasında kullandıkları kaynakların neler olduğu sorulmuştur. Öğretmenlerin verdikleri cevaplar analiz edildiğinde kullandıkları kaynaklarla ilgili 8 farklı koda ulaşılmıştır. Bu kodların sıklık ve yüzdeleri Tablo 9`da verilmiştir.

Tablo 9

SBK'lerin Araştırılması ve Öğretilmesi için Yararlanılan Kaynaklar ile İlgili Kodlara Ait Kodlar, Sıklık ve Yüzde Dăğlımları

\begin{tabular}{cccc}
\hline Kodlar & Siklık & Kodlar & S1klık \\
\hline İnternet / sosyal medya & 9 & Yabancı kitaplar & 2 \\
\hline Ders kitabı & 5 & TV Programları & 1 \\
\hline Popüler dergiler & 5 & Gazete & 1 \\
\hline Yerli kitaplar & 2 & Seminer & 1 \\
\hline Güvenilir internet kaynakları & 1 & & \\
\hline
\end{tabular}

Öğretmenlerin cevapları incelediğinde SBK ile ilgili araştırma yaparken ve sınıf içerisinde ögretimi için en fazla internet ve sosyal medyadan yararlandıkları görülmektedir. Öğretmenlerin interneti en fazla video, fotoğraf gibi görselleri sınıf içerisinde gösterme, sosyal medya gruplarından yapılan paylaşımları takip etme ve konu ile ilgili makaleleri indirme amaçlı kullandıkları belirlenmiștir. Öğretmenlerden sadece bir tanesi internetten aldığı kaynakların güvenilir olmasına dikkat ettiğini su şekilde belirtmiştir:

K25K: "Kaynak olarak internette güvenirliği yüksek olan kaynaklar, mesela uzantısina baklyorum edu ти veya Google akademikten ya da diğer adiyla scholar makale baklyorum."

İngilizce eğitim veren bir okulda çalışan bir öğretmen de Türkiye'de bu konu ile ilgili derste kullanılabilecek kaynakların çok sınırlı olduğunu ve başka ülkelerdeki kaynaklardan yararlandığını şu şekilde belirtmiştir:

E27Ö: "Evet kaynaklar, maalesef Türkçe çok sinırl. Amerika veya İngiltere'deki videolardan konu anlatımı bizim müfredata en yakın ve doğru olanları seçiyoruz."

Öğretmenlerin en fazla kullandıkları diğer kaynakların ise farklı yayınevlerine ait ders kitapları ve TÜBITAK Bilim Teknik gibi popüler dergiler oldukları belirlenmiştir. Bunların dışında yerli 
ve yabancı kitaplar, TV programları ve seminerler SBK ile ilgili öğretmenlerin diğerlerine göre daha az yararlandıkları kaynaklardır. Bu kaynaklarla ilgili iki ögretmenin görüşü şöyledir:

E21Ö: "Kaynak olarak Palme Yayıncılık ve internet ve FDD (Final Dergisi Yayınlart) takip diyorum."

E27K: "Bilim-Teknik dergisi, Interaktif ortamda yayımlanan makaleler, sosyal medyadaki gruplardan."

Bu yanıtlardan yola çıkarak öğretmenlerin yarısından çoğunun SBK'ler ile ilgili bilgiye ulaşırken daha çok güvenirliğini sorgulamadıkları internet tabanlı kaynakları kullanması onların konu ile ilgili gerekli bilgi ve beceriye sahip olmalarında yetersiz olduğu çıkarımı yapılabilir. Öğretmenlerin bazılarının ders kitabi ile sinirli kalmaları ve çoğunun yerli ve yabancı kitapları kullanmamaları onların derinlemesine bilgi sahibi olmalarının önüne geçmesine sebep olduğu söylenebilir.

\section{Öğretmenlerin SBK öğretiminde ihtiyaçları}

Öğretmenlere SBK'nin etkili öğretimi için nelere ihtiyaç duydukları sorulmuş ve verdikleri cevaplara göre ihtiyaç, öneri ve beklentileri belirlenmiştir. Analiz sonuçları öğretmen ihtiyaçlarının çok çeşitli olduğunu ve bu konuda farklı önerileri ve beklentilerinin olduğu görülmüştür. Bu ihtiyaç, öneri ve beklentilerin kodları, sıklık ve yüzde dağılımları Tablo 10'da görülmektedir.

Tablo 10

Öğretmenlerin SBK Öğretimdeki Ihtiyaçları, Önerileri ve Beklentileri ile İlgili Kodların Slklık ve Yüzde Dağllımlart

\begin{tabular}{cccc}
\hline Kodlar & Sıklık & Kodlar & Sıklık \\
\hline Materyal & 5 & Yabancı kaynak & 1 \\
\hline Öğretmen eğitimi & 5 & Özveri & 1 \\
\hline Uygun çalışma koşulları & 3 & Öğrenci ve öğretmen yükünün azaltılması & 1 \\
\hline Paylaşım & 2 & Günlük hayattan örnekler & 1 \\
\hline Video ve görseller & 2 & Güvenilir kaynak & 1 \\
\hline Seminerler/Konferanslar & 2 & Duygusal uyarıcılar & 1 \\
\hline Disiplinler arası yaklaşım & 2 & Hazır ders planları & 1 \\
\hline
\end{tabular}

Yanıtlar incelendiğinde öğretmenlerin en fazla öğretmen eğitimine ve gerekli materyallere ihtiyaçları olduğu belirlenmiştir. Öğretmenlerin düşük öz yeterlilik inançlarına sahip olmaları SBK'ler ile ilgili yeterli bilgi ve beceriye sahip olmamalarıyla yakından ilişkili olduğu söylenebilir. Bu nedenle öğretmen eğitimi ön plana çıkmaktadır. Öğretmen eğitimine önemli ölçüde ihtiyaçları olduğunu düşünen öğretmenlerden biri düşüncesini şu şekilde açıklamıştır:

E21Ö: "Laboratuvar ortamını daha etkin kullanmayı tercih ederdim. Laboratuvar ortamı örneğin geçen hafta göz kestik beyin kestik çok heyecanlandılar. Ancak daha etkili kullanmak için eğitim almayl, yenilenmeyi isterdim."

Diğer bir öğretmen ise görüşünü şöyle açıklamıştır:

E19K: "Yani aynı düz anlatıma devam. Her müfredat değişiminde her ilden hocalar eğitime alınsak ya da 5 yılda bir yenilenme çalışması olsa ve sınava alınsak sınavdaki başarımıza göre performans alsak. Hizmet içi eğitimine gidenler de gelince bilgilerini bizimle paylaşmıyor." 
$\mathrm{Bu}$ örnek sürdürülebilir ve yaygınlaştırılabilir hizmet içi eğitim modellerine olan ihtiyacı yansıtmaktadır. Öğretmenlerden bazıları da materyal eksikliklerinin olduğunu ve bunların sağlanması gerektiğini önermişlerdir. Öğretmenler materyal olarak özellikle SBK'ler ile ilgili hazır ders planları, öğretmen kitapları, farkındalık yaratmak için kullanılabilecek afis ve sloganlar, laboratuvar malzemeleri ve kısa film/video gibi görsellere ihtiyaç duyduklarını ifade etmişlerdir. Örneğin bir öğretmen bu beklentisini şöyle dile getirmiştir;

K23K: “Ders planlarının hazırlanmış olması çünkü bunlara yönelik planlar yok. Nasıl hazırlanacă̆ına dair ögretim, yöntem, teknik bilgiler, bilgisayarda plan hazırlama, çeşitlendirmelere ihtiyacımı var. Bununla birlikte nereden, nasıl başlayacağımı bilmiyorum. Öğretime yol gösteren adım adım ilerleyen ders planları rahatlatacaktır."

şeklinde ifade ederken diğer bir öğretmen ise E21Ö: "Kısa film veya video gibi materyaller, örneğin organ nakli yapılan bir hasta ile ilgili kisa film gibi materyaller olmalı" şeklinde belirtmiş̦tir. Laboratuvar kullanımı ile ilgili eksikliği belirten bir öğretmen düşüncesini aşağıda belirtildiği gibi açıklamıştır:

E20K: "Biz laboratuvar yeterince kullanamiyoruz. Nedeni ise malzeme var ama eski veya kullanım süresi geçmiş. Laboratuvarını aktif kullanmaya ihtiyacım var."

Bir diğer öğretmen ise teknolojik yeterliliğini artırmaya ihtiyacı olduğunu şu sözlerle dile getirmiştir:

K20K: "Öğretmen gerektiğinde mikroskobu tamir etmeli soğandan DNA extracsiyonu you tube'dan seyrettiriyorum onu da abim ögretti youtube'dan film indirmeyi indiremediklerimi seyrettiremiyorum ki bazı okullarda daha yeni akıll tahta geldi onlar daha vahim. Bir proje yaparsanı projenizde video kesmeyi ögretseniz teknolojik yeterliliğimin artırllmasına ihtiyacım var. Eve ödev veriyorum öğrencilere ama köyde internet yok."

Bu örnekte öğretmen sadece kendi teknoloji kullanım yeterliliği değil, öğrencilerin SBK'de araştırma yapması için gerekli olan kaynakların yetersizliğinden de bahsetmiştir. Öğretmen cevapları incelendiğinde üç öğretmenin çalışma koşullarının daha uygun olması gerektiğini önerdikleri belirlenmiştir. Bu öğretmenler laboratuvar koşullarının, okulun fiziksel koşullarının ve donanımının iyileştirilmesi gerektiğini düşünmektedirler. Disiplinler arası yaklaşımın yetersizliğini belirten öğretmenlerden biri bu görüşünü

K18K: “Öğrenciler yeterli değil. Kavramsal olarak yeterli bilgi yok. Disiplinler arast iletişim kurma yetersizliği, okullarda yapılan konu ile ilgili sosyal programlar, farkındalık çalışmalarl yetersiz." şeklinde ifade etmiştir.

Bunların dışında diğer öneriler incelendiğinde öğretmenlerin SBK ile ilgili daha fazla video ve görsellerin olması gerektiğini, katılabilecekleri seminerler ve konferansların düzenlenmesini istedikleri belirlenmiştir. Ayrıca diğerlerine göre İngilizce öğretim yapan öğretmenler kullanılabilecekleri yabancı kaynak, sınıfta kullanılabilecek günlük hayattan örnekler ve sınıfta öğrencilerin konu ile ilgili motivasyonlarını artırıcı duyusal uyarıcıları kaynaklarının artırılması gerektiğini önermişlerdir. Ancak bu öğretmenlerin özel okullarda çalıştığı düşünüldüğünde kaynak ve diğer ihtiyaçlarının okul yönetimine bildirilmesi, teknolojik yeterlilikleri daha iyi durumda olan bu okullarda duyusal uyarıcı kaynaklarını kendilerinin kolaylıkla ulaşılabileceği gerçeği de kaynak ve materyal sorununu dile getirmeleri açısından düşündürücüdür. Bu bulgulara göre, öğretmen eğitiminin en fazla ihtiyaç duyulan unsur olması öğretmenlerin SBK ile ilgili bilgi ve becerilerinin yeterli olmayışının farkında olduklarını göstermektedir. Öğretmenlerin hem alan bilgisinin hem de pedagojik alan bilgisinin yeterli olmaması diğer görüşme sorularına verdikleri 
yanıtlarda ve örneklerde de görülmektedir. SBK'ler ile ilgili öğretmen eğitimi açısından yetersiz olan öğretmenlerin materyal ve diğer kaynak (video, ders planı, vb) eksikliklerinin de olduğunu belirtmeleri onların bu konu ile ilgili yeterli bilgiye neden sahip olmadıklarının sebepleri olarak gösterilebilir.

\section{Tartışma, Sonuç ve Öneriler}

$\mathrm{Bu}$ çalışmada öğretmenlerin SBK ile ilgili algıları ve bunları sınıflarında nasıl öğrettikleri araştırılmıştır. Araştırmanın sonuçlarına göre Lise Biyoloji öğretmenlerinin SBK tanımını yapamadıkları görülmüştür. Bu sonuç, Han- Tosunoğlu ve İrez (2017) yaptığı çalışmanınkiyle benzerlik göstermektedir. Topçu, (2015) tarafından yapılan tanıma göre fen ve teknoloji içerikli olan; etik, ahlaki ve yasal ikilemler içeren; tartışmalı; karmaşık konularda karar verme becerileri gerektiren SBK konusunda öğretmenlerin yaptığı açıklamaların bu kavramları içermediği ve öğretmenlerin beklenen anlamayı gerçekleştirmediği tespit edilmiştir. Buna bağlı olarak da öğretmenlerin verdikleri örneklerin hem yetersiz olduğu hem de konu ile ilgili olmadığ belirlenmiştir. Alan yazındaki çalışmalarda da SBK'lerin öğretimini sınırlayan etmenler arasında ilgili materyallerin bulunamaması, öğretim süresinin yetersizliği ve öğretmenlerin düşük öz yeterlilik inançlarına sahip olmaları, bu anlamanın gerçekleşmemesinin nedenleri olarak gösterilmektedir (Abd-El-Khalick ve Choi, 2006; Kara, 2012).

Öğretmenlerin SBK konusunda yeterli anlamaya sahip olmamalarının diğer nedenleri, eski ve yeni öğretim programlarında SBK kavramının geçmemesi (MEB, 2013; MEB, 2018) ve kendilerinde belirtiği gibi bu konuda hiçbir hizmet içi eğitim almamaları olabilir. Kullandıkları kaynaklarda da bu konuların SBK olarak tanımlanmaması da ayrı bir neden olarak gösterilebilir. Öğretmenlerin SBK tanımını bilmemesine rağmen çevre eğitimi, GDO, aşılar ve organ nakli örnekleri verildiğinde bu konuları bildikleri ve sınıflarında işledikleri anlaşılmıştır. Yapılan birçok çalışmada da olduğu gibi (Bossér, Lundin, Lindah, ve Linder, 2015; Reis ve Galvao, 2009) öğretmenlerin bu araştırmada seçilen konularla ilgili yeterli alan bilgisine sahip olmadıkları görülmüş̧ür.

Öğretmenlere verilen başlıklar arasından en fazla bilgi eksikliğine sahip olunan ve en az uygulama örnekleri sundukları konunun aşı olduğu tespit edilmiştir. Aşıların bağışıklık üzerindeki olumlu etkilerine rağmen, her zaman çocuklara yapılacak aşıların etkililiği, güvenliği ve gerekliliği konusundaki şüpheler nedeniyle, aşılara karşı bireysel ve toplumsal direnç bulunmaktadır (Streefland, 2001). Bu şüpheleri gidermenin ve ebeveynleri, çocuklarının bağışıklığı konusunda sorumluluk sahibi bir şekilde kararlar almasını sağlamanın anahtarı eğitimden geçmektedir (McKee ve Bohannon, 2016). Bu çalışmadaki katılımcı öğretmenlerin aşılar konusunda tepkili olduğuna yönelik bir kanıt bulunmamakla birlikte, bu tepkilerin farkında olduklarını ya da tepkili olabilecek öğrencilere yönelik ne tür yaklaşımlarda bulunulacağına yönelik de bir gösterge bulunmamaktadır. Oysa öğretmenlerin olası tepkilere cevap verecek ve bu konuda öğrencilerini bilgilendirecek düzeyde olması önemlidir. Bu nedenle, Biyoloji öğretmenlerinin bu konularda bilgilendirilmesi önem taşımaktadır. Öğretmenler ayrıca, öğrencilerine aşı konusundaki iddiaları ve bilimsel bilgiyi eleştirel bir bakış açısıyla değerlendirebilecekleri ortamları sunabilmelidirler. Öğretmenlerin SBK öğrenilmesinde genel olarak en çok geleneksel yöntemlerden okuma, yazma, düz anlatım, soru-cevap, gözlemi kullandıklarını belirtmiştir.

SBK'lerin öğretiminde argümantasyon, diyolojik tartışma (Kılınç, Demiral, Kartal, 2017), ortak bilgi yapılandırma modelinin (Bakırcı, Altun, Şahin, Sağdıç, 2018) kullandığı görülürken, bu araştırmadaki öğretmenlerin daha çok geleneksel yöntemlere eğilim gösterdiği, SBK'lerin öğretiminde etkili olan diğer yöntem ve teknikleri kullanmadıkları görülmektedir. Bu durumun öğretmenlerin SBK'ler ile ilgili hem alan bilgisine hem de pedagojik alan bilgisine sahip olmadıklarından kaynaklandığı söylenebilir. Tartışmayı 5 öğretmen kullanırken, argümantasyon, münazara gibi eleştirel düşünme becerisi, kanıta dayalı karar verme becerisi, iletişim ve fen kavramlarının genişlemesine öğrenildiği yöntemleri kullanmadıkları belirlenmiştir. Simonneaux 
(2014) araştırma sonucunda olduğu gibi tartışmayı kullanan öğretmenlerin tartışmayı planlamadıkları, yapılandırmada ve yönetmede sorunlar yaşadığ 1 görülmektedir. Yine grup çalışması yaptırdıklarını belirten öğretmenlerin, grup çalışması, araştırma ve tartışmaları planlamadığı görülmektedir. Özellikle tartışmada bir öğretmen tartışma yaparken kendi görüşünden farklı görüşlerin çıkması sonucu tartışmayı yönetmekte zorlandığını ve artık derslerinde tartışma yaptırmak istemediğini belirtmiştir. Oulton, Dillon ve Grace, (2004) bunu fikirlerin siyasi, ahlaki ve etik olarak farklı olmasıyla açıklarken bu araştırmada yer alan öğretmen (K32Ö) tartışmalarda dini öğretilerin öne çıkmasından duyduğu rahatsızlığı dile getirmiştir. Bu sonuç, öğretmenlerin sınıftaki tartışmayı yürütme becerisinin geliştirilmesi gerektiğine işaret etmektedir. $\mathrm{Bu}$ amaçla, öğretmen yetiştirme programları ve hizmet içi eğitimler, öğretmen adaylarına ve öğretmenlere SBK'yi kanıta dayalı olarak tartışma becerisini kazandıracak ve onların da öğrencilerine bu beceriyi kazandırmaya yönelik etkinlikler ve öğretim ortamları hazırlayabilecek yeterliliği kazandıracak şekilde tasarlanmalıdır.

Araştırmada elde edilen bir diğer sonuca göre, öğretmenlerin bu konuları derste işlemeden önce yeterli araştırma yapmadıkları, yaptığını düşünenlerin ise daha kıdemli ve bilgili arkadaşına sorması, ya da yeterli ve güvenilir kaynak araştırması yapmadığı, bilimsel kaynakları kullanmadığı veya kullanmayı bilmedikleri ortaya çıkmıştır. Bu sonuç, Gürbüzoğlu-Yalmancı ve Gözüm'ün (2016) Biyoloji öğretmen adaylarıyla yaptığ 1 çalışmadan elde ettiği bulgularla örtüşmektedir. Benzer şekilde Alaçam-Akşit (2011) tarafından yapılan çalışmada da öğretmen adaylarının SBK'lerle ilgili olarak sahip oldukları bilgi ve görüşleri en çok medyadan (TV, internet, gazete, dergi) edindikleri ortaya çıkmıştır. Bunun yanında İngilizce bilen, özel okulda çalışan öğretmenlerin derslerinde farklı örnekler kullanabildiği, uluslararası kaynaklardan yararlandıkları, yüksek lisans ve doktora derecesine sahip olan öğretmenlerin ise diğer öğretmenlere göre öğretim sürecinde öğrencileri daha aktif kılan uygulamalar planladıkları söylenebilir. Öğretmenlerin bu konuları öğretmede nelere ihtiyacı olduğu sonucuna bakıldığında öğretim materyallerine olan ihtiyaç ve hizmet içi öğretmen eğitimi öne çıkmaktadır. SBK öğretiminde öğretim materyallerin bulunmaması etkili öğretimi engelleyen bir faktör olarak ifade edilmiştir. Alan yazındaki çalışmalarda da SBK'lerin öğretimini sınırlayan etmenler arasında ilgili materyallerin bulunamaması, öğretim süresinin yetersizliği ve öğretmenlerin düşük öz yeterlilik inançlarına sahip olmaları gösterilmektedir (Kara, 2012; Lee, Abd.El.Khalick ve Choi, 2006). Bu çalışmada da öğretmenlerin aynı eksikliği dile getirmiş olmaları, öğrenme ortamlarının materyal olarak zenginleştirilmesi gerektiği sonucunu ortaya çıarmaktadır. Tüm bu sonuçlardan genel bir yorum yaptığımızda ise 2005 yılından bu yana çalışılan ve son on yıldır popüler olan SBK'nin ne olduğunun, halen öğretmenler ve konuyla en ilişkili alan olan Biyoloji öğretmeleri tarafından bilimsel olarak tanımlanamıyor olmasıdır. Bunun sebepleri olarak en öne çıkan neden olarak öğretmen eğitiminde öğretmen adaylarına yaşam boyu öğrenme becerisi kazandırılmaması, akademik çalışmaların öğretmenlerin yararlanacağı etkinlik örneklerine olan ihtiyacı karşılayamaması, öğretmen eğitimi ve akademik uygulamaların okul boyutunun yetersiz kalması, öğretmenlerin teknolojik ve bilimsel okuryazarlık becerilerinin geliştirilmesine ihtiyaç olduğu kanısıdır. Konuyla ilgili öğretmenlerin kullanacağı bilimsel kaynaklara, öğretim materyallerine, zengin öğrenme ortamlarına ve dersin işlenişine rehberlik edecek kaynaklara gereksinim vardır. Tüm bu sorunlara çözüm olarak, Biyoloji öğretim programlarında SBK tanımının yapılması, öğretim programlarının kazanımlarıyla ilgili örnek etkinlikleri içeren kitaplar, videolar ve özellikle web sayfaları aracılığıyla öğretmenlerle paylaşılması, bu alanda çalışan akademisyenlerimizin özellikle sınıf içi uygulamalarda tartışma, argümantasyon gibi eleştirel düşünme becerilerini geliştiren yöntemlerin uygulanmasında öğretmenlere mentörlük rolünü üstlenmesi önerilmektedir. Ayrıca akademik çalışmalarda sınıf içi uygulamalara daha çok ağırlık verilerek gerçekleştirilmesi, öğretmenlerin güncel konulardaki alan bilgisi yeterliliklerinin geliştirilmesi, bilimsel araştırma kaynakları ve teknoloji yeterliliklerinin geliştirilmesi için sık sık hizmet içi doğrudan uygulamalı eğitimlere alınması ve öğrenme ortamlarının SBK'lerin öğrenilmesinde kullanılacak öğretim materyalleriyle zenginleştirilmesi önerilmektedir. 


\section{Etik Kurul Onay Bilgileri}

Bu çalışma, İstanbul Aydın Üniversitesi Etik Komisyonu'nun 10.01.2017 tarih ve 2018/2 sayılı kararı ile araştırma ve yayın etiğine uygun olarak gerçekleştirilmiştir.

\section{Kaynaklar}

Alaçam-Akşit, A. C. (2011). Sinıföğretmeni adaylarının sosyobilimsel konularla ve bu konuların ögretimiyle ilgili görüşleri. (Yayınlanmamış yüksek lisans tezi). Ege Üniversitesi Sosyal Bilimler Enstitüsü, İzmir.

Altuntaş, E. C., Yılmaz, M. ve Turan, S. L. (2017). Biyoloji öğretmen adaylarının sosyobilimsel bir konudaki eleştirel düşünmelerinin empati açısından incelenmesi. Bartın Üniversitesi Eğitim Fakültesi Dergisi, 6(3), 915-931. doi: 10.14686/buefad.311276

Bakırcı, H., Artun, H., Şahin, S. ve Sağdıç, M. (2018). Ortak bilgi yapılandırma modeline dayalı fen öğretimi aracılığıyla yedinci sınıf öğrencilerinin sosyobilimsel konular hakkındaki görüşlerinin incelenmesi. Eğitimde Nitel Araştırmalar Dergisi, 6(2), 207-237. doi:

10.14689/issn.2148 - 2624.1.6c2s10m

Barber, M. (2001). A comparison of NEAB and Salters A-level Chemistry: Students views and achievements. York, UK: University of York.

Bossér, U., Lundin, M., Lindahl, M., \& Linder, C. (2015). Challenges faced by teachers implementing socio-scientific issues as core elements in their classroom practices. European Journal of Science and Mathematics Education. 3, 159-176.

Büyüköztürk, Ş., Kılıç-Çakmak, E., Akgün, Ö. E., Karadeniz Ş. ve Demirel, F. (2018). Eğitimde bilimsel araştırma yöntemleri. Ankara: Pegem Yayınları.

Cohen, L., Lawrence, M. ve Morrison, K. (2006). Research methods in education. London and New York: Routledge Falmer.

Creswell, J. W. (2007). Research design: Qualitative, inquiry and research design: Choosing among five approaches. Thousand Oaks: Sage.

Dori, Y. J., Tal, R. T., \& Tsaushu, M. (2003). Teaching biotechnology through case studiescan we improve higher order thinking skills of nonscience majors? Science Education, 87(6), 767-793. doi: 10.1002/sce.10081

Driver, R., Newton, P., \& Osborne, J. (2000). Establishing the norms of scientific argumentation in classrooms. Science Education, 84, 287-312.

Ekborg, M. , Ottander, C., Silfver, E., \& Simon, S. (2013). Teachers' experience of working with socioscientific issues: A large scale and in-depth study. Research in Science Education, 43(2), 599-617. doi: 10.1007/s11165-011-9279-5

Gürbüzoğlu -Yalmancı, S. ve Gözüm, A. İ. C. (2016). Fen bilgisi öğretmen adaylarının (GDO) sosyobilimsel konusuna yönelik araştırma davranışlarının incelenmesi. Ahi Evran Üniversitesi Kırşehir Eğitim Fakültesi Dergisi, 17(1), 499-515.

Han-Tosunoğlu, Ç ve İrez. S, (2017). Biyoloji öğretmenlerinin sosyobilimsel konularla ile ilgili anlayışları. Uludă̆ Üniversitesi Ĕ̈itim Fakültesi Dergisi, 30(2), 833-860. doi: $10.19171 /$ uefad.369244

Kara, Y. (2012). Pre-service biology teachers' perceptions on the instruction of socio-scientific issues in the curriculum. European Journal of Teacher Education, 35(1), 111-129. doi: $10.1080 / 02619768.2011 .633999$

Kılınç, A., Demiral, U., \& Kartal, T. (2017). Resistance to dialogic discourse in SSI teaching: The effects of an argumentation-based workshop, teaching practicum, and induction on a preservice science teacher. Journal of Research in Science Teaching, 54(6), 764-789. doi: 10.1002/tea.21385

Klosterman, M. L., \& Sadler, T. D. (2010). Multi-level assessment of scientific content knowledge gains associated with socioscientific issues-based instruction. International Journal of Science Education, 32(8), 1017-1043. doi: 10.1080/09500690902894512

Lee, H., Abd-El-Khalick, F., \& Choi, K. (2006). Korean science teachers' perceptions of the introduction of socio-scientific issues into the science curriculum. Canadian Journal of Science, Mathematics and Technology Education, 6(2), 97-117. 
Lee, M. K., \& Erdogan, I. (2007). The effect of science-technology-society teaching on students' attitudes toward science and certain aspects of creativity. International Journal of Science Education, 29(11), 1315-1327. doi: 10.1080/09500690600972974

Levinson, R. (2006). Teachers' perceptions of the role of evidence in teaching controversial socio scientific issues. The Curriculum Journal, 17(3), 247-262. doi: $10.1080 / 09500690600560753$

Levinson, R. (2007). Towards a pedagogical framework for the teaching of controversial socioscientific issues to secondary schools in the age range 14-19 (Unpublished doctoral dissertation). University of London, Institute of Education, London, UK.

Lincoln, Y. S., \& Guba, E. G. (1985). Naturalistic inquiry. Beverly Hills, CA: Sage.

Louca, L.Lincoln, Y. S., \& Denzin, N. K. (1994). The fifth moment. In N. K. Denzin,, \& Y. S. Lincoln, Handbook of qualitative research (pp. 575-586), Thousand Oaks, CA: Sage.

McKee, C., \& Bohannon, K. (2016). Exploring the reasons behind parental refusal of vaccines. The Journal of Pediatric Pharmacology and Therapeutics, 21, 104-109. doi.org/10.5863/1551-6776-21.2.104

Miles, M. B., \& Huberman, A. M. (1994). Qualitative data analysis: An expanded sourcebook. London: Sage Publications.

Milli Eğitim Bakanlığı [MEB] (2013). 3-4-5-6-7 ve 8. sinıflar Fen Bilimleri dersi öğretim programı. Ankara: Talim Terbiye Kurulu Başkanlığı.

Milli Eğitim Bakanlığ1 [MEB] (2018). 3-4-5-6-7 ve 8. sinıflar Fen Bilimleri dersi öğretim programı. Ankara: Talim Terbiye Kurulu Başkanlığı.

Organisation for Economic Co-operation and Development [OECD] (2006). Assessing scientific, reading and mathematical literacy: A framework for PISA 2006. Paris: OECD.

Oulton, C., Day, V., Dillon, J., \& Grace, M. (2004). Controversial issues-teachers' attitudes and practices in the context of citizenship education. Oxford Review of Education, 30(4),

489-507. doi: 10.1080/0305498042000303973

Parchmann, I., Gräsel, C., Baer, A., Nentwig, P., Demuth, R., \& Ralle, B. (2006). "Chemie im Kontext": A symbiotic implementation of a context-based teaching and learning approach. International Journal of Science Education, 28(9), 1041-1062. doi: $10.1080 / 09500690600702512$

Patton, M. Q. (2002). Qualitative research and evaluation methods ( $3^{\text {rd }}$ Edition). Beverly Hills, CA: Sage.

Pitiporntapi, S., \& Srisakuna, S. (2017). Case studies of the development of science teachers' practices of socio-scientific issue (SSI)-based teaching through a professional development program. International Education Studies, 10(1), 56-66. doi:10.5539/ies.v10n1p56

Reis, P., \& Galvao, C. (2009). Teaching controversial socio-scientific issues in biology and geology classes: a case study. Electronic Journal of Science Education, 13(1), 162-185.

Sadler, T. D., \& Zeidler, D. L. (2005). Patterns of informal reasoning in the context of socioscientific decision making. Journal of Research in Science Teaching, 42(1), 112138. doi: 10.1002/tea.20042

Sadler, T. D., Barab, S. A., \& Scott, B. (2007). What do students gain by engaging in socioscientific inquiry? Journal of Research in Science Teaching, 37, 371-391. doi: 10.1007/s11165-006-9030-9

Sadler, T. D. (2009). Situated learning in science education: Socio-scientific issues as contexts for practice. Studies in Science Education, 45, 1-42. doi: 10.1080/03057260802681839

Simonneaux, L. (2014). Questions socialement vives and socio-scientific issues: New trends of research to meet the training needs of postmodern society. In C. Bruguiere, A. Tiberghien, \& P. Clement (Eds.), Topics and trends in current science education (pp. 37-54). Dordrecht, The Netherlands: Springer, Verlag.

Streefland, P. H. (2001). Public doubts about vaccination safety and resistance against vaccination. Health Policy, 55(3), 159-172. doi: 10.1016/S0168-8510(00)00132-9 
Sürmeli, H., ve Sahin, F. (2012). Preservice science teachers' opinions and ethical perceptions in relation to cloning studies. Cukurova University Faculty of Education Journal, 41(2), 76-86.

Topçu, M. S. (2010). Development of attitudes towards socioscientific issues scale for undergraduate students. Evaluation and Research in Education, 23(1), 51-67.

Topçu, M. S. (2015). Sosyobilimsel konular ve ögretimi. Ankara: Pegem.

Wu, Y-T., \& Tsai, C., C. (2007). High School Students' Informal Reasoning on a Socioscientific Issue: Qualitative and quantitative analyses, International Journal of Science Education, 29(9), 1163-1187. doi: 10.1080/09500690601083375

Yıldırım, A. ve Şimşek, H. (2016). Sosyal bilimlerde nitel araştırma yöntemleri. Ankara: Seçkin Yayınları.

Zeidler, D. L., \& Sadler, D.L. (2011). An inclusive view of scientific literacy: Core issues and future directions of socioscientific reasoning. New York: Routledge/Taylor \& Francis.

Zeidler, D. L., Sadler, T. D., Simmons, M. L., \& Howes, E. V. (2005). Beyond STS: A research-based framework for socioscientific issues education. Science Education, 89(3), 357-377. https://doi.org/10.1002/sce.20048

\section{Introduction}

\section{Extended Abstract}

The skills of critical thinking, making informed decisions and scientific literacy are among the goals of science education. Socio-scientific issues (SSI) are socially, economically, politically, and morally controversial issues that are based on scientific research results, practices, or problems that arise in practice, and whose results are most influential on living life, nature. Many researchers of science education stress the benefits of teaching SSI, and these topics have been included in teaching programs for decades. SSI in science teaching was first included in Turkish science curriculum as environmental problems and health issues in 2013. However, the specific topics that were directly related to these issues, such as GMO or organ transplantation are not included in Turkish science curriculum. Although considerable amount of literature emphasized teachers' understanding and teaching of SSI, researches investigating biology teachers' understanding of environmental pollution, GMO, vaccines and transplantation of organs specifically and their incorporation of these topics into their teaching were rarely found. In order to fulfil this gap, the study presented here aimed to identify how biology teachers performed SSI education with students and what they needed in this regard. For this purpose, phenomenology, one of the qualitative research designs was used in this study.

\section{Method}

The study group consisted of fourteen biology teachers ( 9 females and 5 males) working in different cities in Turkey in the fall semester of the 2017-2018 academic year. In order to probe into teachers' understanding of SSI and their incorporation of these topic in their teaching, the researchers of this study used maximum variation and criterion sampling methods, which are among the purposeful sampling methods. To ensure the maximum variation, male and female teachers who worked in different schools, including both private and public schools were selected as a sample group. Data were obtained through face-to-face semi-structured interviews, telephone and internet calls (face-time and skype) by using a data collection tool comprising six open-ended questions which were prepared by researchers. The questions included the definition of SSI and examples of it, what they understood by the concepts of environmental pollution, GMO, vaccines and transplantation of organs, whether they searched these topics, how they taught these topics and constraints they experienced during teaching these topics. In order to analyze data, codes and themes were developed through the use of the content analysis method. Two of the researchers in this study conducted the transcription, coding, and analysis of the interviews independently. The results were presented under the categories of; understanding SSI, SSI examples, general teaching process of SSIs, resources used during teaching SSI, needs for the teaching of SSI. 


\section{Result and Discussion}

The results showed that teachers could neither define SSI nor give sufficient or relevant examples of SSI. Although they were unable to explain SSI, their explanations indicated that they were informed about the topics of environmental pollution, GMO, vaccines and transplantation of organs and taught these topics to their students. However, the findings revealed that they did not have enough content knowledge about these topics. The results also showed that the teachers had the least knowledge about vaccines among the selected socio-scientific topics in the current study. No evidence was found to infer that the teachers were aware of the anti-vaccine movement or other concerns about vaccines in public. Therefore, it seemed crucial to inform teachers about these issues and provide opportunities to enable them to critically evaluate the claims and scientific knowledge about vaccines.

Reading, writing, lecturing, questioning and observing were the most commonly used teaching methods in the teachers' instruction. In other words, they mostly used traditional methods without searching for other methods and techniques, such as evidence-based argumentation, debate, etc. to facilitate understanding of SSI. On one hand, the senior teachers do not sufficiently search for sources of information about SSI. On the other hand, the teachers who had English language proficiency used various instructional methods and techniques in their teaching and read international sources to have information about SSI. Those who had masters or $\mathrm{PhD}$ degrees were able to provide richer and more organized instructional environments.

Considering teachers' needs to teach these topics effectively, one of them argued that was necessary to enrich instructional materials in schools and provide teachers more in-service teaching service programs. In conclusion, biology teachers should be provided opportunities to increase their knowledge level about SSI and effective methods to teach SSI that will enable them to create scientific literate citizens who are actively engaged in learning, critically evaluate information based on evidence and make informed decisions about SSI. Increasing teachers' participation in academic and in-service programs seems crucial in this respect. 